\title{
Methods of calculating ship resistance on limited waterways
}

Emilia Skupień, M. Sc.

Jarosław Prokopowicz, M. Sc.

Wrocław University of Technology

\begin{abstract}
Nowadays predicting transportation costs is more and more important. Most significant part of inland navigation's costs are the costs of fuel. Fuel consumption is related to operating conditions of ship's propulsion system and its resistance. On inland waterways the ship resistance is strictly related to the depth of the waterway.

There is a tendency to build a formula that allows its user to calculate the resistance of any inland waterway vessel, but researches claim that most of them are accurate only for particular types of ships and/or operating conditions. The paper presents selected methods of calculating ship resistance on inland waterways. These methods are examined for different types of ships and different conditions using results of model tests.

The performed comparison enabled selecting the best option for pushboats and pushed barge trains, but also showed that any of the tested methods is good enough to be used for calculating the resistance of motor cargo vessels. For this reason, based on known equations and using the regression method, the authors have formulated a new method to calculate the resistance of motor cargo vessels on limited waterway. The method makes use of ship's geometry and depth of waterway in relation to ship's speed. Correlating the ship's speed with its resistance and going further with fuel consumption, enables to calculate the costs of voyage depending on the delivery time.

The comparison of the methods shows that the new equation provides good accuracy in all examined speed ranges and all examined waterway depths.
\end{abstract}

Keywords: ship resistance, inland waterways, regression analysis

\section{Introduction}

In terms of inland waterways, ships sail in shallow water. Attention shall be paid to this fact because, unlike sea waters of unlimited depth, here the sailing conditions depend on the depth of the waterway and on the width of the hull of the ship.

The flow of water between the bottom of the river and the ship can be compared to the flow between parallel planes - the moving one (ship) and the steady one (bottom of the river).

This approach assumes a fully developed turbulent flow. However, it does not take into account the surface roughness of the river bed, nor changes in the pressure gradient.

Reduction of the depth of the waterway provokes different phenomena to take place, and changes the character of interactions between the ship and the waterway.

For example, the velocity of the water around the hull is significantly greater than the ship speed. This is due to the reduction of the waterway cross section by the hull. Another result of this phenomenon is a reverse flow, the speed of which is the average speed increase of the water flow relative to the hull. The value of this speed depends on the necking and shape of the hull, and may be greater than the ship speed. This phenomenon is negligible when sailing on unlimited waterway (at sea).

The research has been made to increase the accuracy of fuel consumption estimation of an inland vessel in real-time. The final goal is to build and implement on-board a device helping the crews to minimize fuel consumption during sailing in waterways characterized by remarkably different hydrological conditions (for example Odra river).

The most important assumption is to calculate the resistance of ship's hull in real-time, for the crew to be able to correct immediately the propulsion system parameters and minimize this way the fuel consumption. For this reason CFD methods and complicated mathematical formulas were rejected. 


\section{Calculation of ship resistance on limited waterway}

The equations of motion of a vehicle assume that the driving force must overcome the resistance force. Exact determination of the total motion resistance of the ship is very important for proper selection of the propeller and the entire propulsion system. Very important factors are the economic aspects.

The total resistance $\mathrm{R}_{\mathrm{T}}$ of the ship is usually calculated using the following equation:

$$
\mathrm{R}_{\mathrm{T}}=\frac{1}{2} \cdot \mathrm{C}_{\mathrm{T}} \cdot \rho_{\mathrm{H}_{2} \mathrm{O}} \cdot \mathrm{V}^{2} \cdot \mathrm{S}
$$

The resistance of the hull can be determined by approximate methods, or computations making use of CFD (Computational Fluid Dynamics), or based on the results of model tests.

The essence of the model tests is observation of physical phenomena occurring in the model flow and converting them to a real object. In such tests the hull resistance force is measured, depending on the towing speed of the model ship in the model basin.

Model tests are not carried out for each type of ship, and for years attempts have been made to create approximate formulas which will make it possible to calculate the resistance of real ships of any geometry.

In order to validate these methods, performance parameters of individual ships tested in model basins are calculated and compared with the results obtained using the approximate formulas.

One of possible applications of the approximate formulas is presented in [1]. The authors assumed that at a fixed speed and geometry of the vessel, the total resistance is a function of main particulars of the ship and waterway parameters.

$$
R_{T}=\left.f\left(\frac{L}{B}, \frac{B}{T}, \frac{\nabla^{\frac{2}{3}}}{S}, \frac{\mathrm{L}}{\nabla^{\frac{1}{3}}}, \frac{\mathrm{h}}{\mathrm{T}}, \mathrm{C}_{\mathrm{B}}\right)\right|_{F_{n L}=\text { const }}
$$

In the analyzes the authors assumed that the total resistance coefficient CT refers to a fixed standard length of the ship, which is $61.0 \mathrm{~m}$. The Froude number based conversion of standard dimensions to actual dimensions is expressed in the form:

$$
F_{n \nabla}=\frac{V}{\sqrt{g \cdot \frac{\nabla}{S}}}=\frac{V_{61}}{\sqrt{g \cdot \frac{\nabla_{61}}{S_{61}}}}
$$

The calculations were performed for motor cargo vessels and four different arrangements of barge trains. For each type of vessel the results of model tests were taken into account. The following vessels were considered: trains of the pushed barges EUROPA II and DU (tested in Duisburg) [2] and [3], the pushed barge train BIZON [4], the motor cargo vessel BM-500 [5], the motor cargo vessel Odrzańska Barka Motorowa (OBM) [6], and the motor cargo vessel DUISBURG [7].
The multiple regression analysis and the stepwise multiple regression analysis yielded the formula:

$$
\begin{gathered}
\ln \left(C_{T \text { 61 }}\right)=A_{0}+A_{1} \frac{L}{B}+A_{2}\left(\frac{B}{T}\right)^{2}+A_{3}\left(\frac{\nabla^{\frac{2}{3}}}{S}\right)^{2}+ \\
+A_{4}\left(\frac{\mathrm{L}}{\nabla^{\frac{1}{3}}}\right)^{2}+A_{5} \ln \frac{h}{T}+\left.A_{6} \cdot C_{B}\right|_{F_{n}=\text { const }}
\end{gathered}
$$

where the coefficients A0 to A6 depend on the type of vessel, the arrangement of barges in a train, the geometry of the underwater part of the hull, and the Froude number defined by equation (3).

The results calculated using Equation (4) are compared with the results of the model tests in Figs. 1, 2 and 3. Total resistance of the ship was determined from Equation (1) with regard to the conversion of the standard length to the actual length of the ship.

The results of calculations for the BM-500 were compared to the results of model tests. Due to the small range of Froude number for which the coefficients A0 to A6 are given, Equation (4) can only be applied for a narrow range of speeds.

The resistance coefficient for the model ship calculated using Equations (4) and (3) (Froude model law) was converted to real dimensions of motor cargo vessel. The calculated results in the non-dimensional form are presented in Figs. 1,2 and 3 .

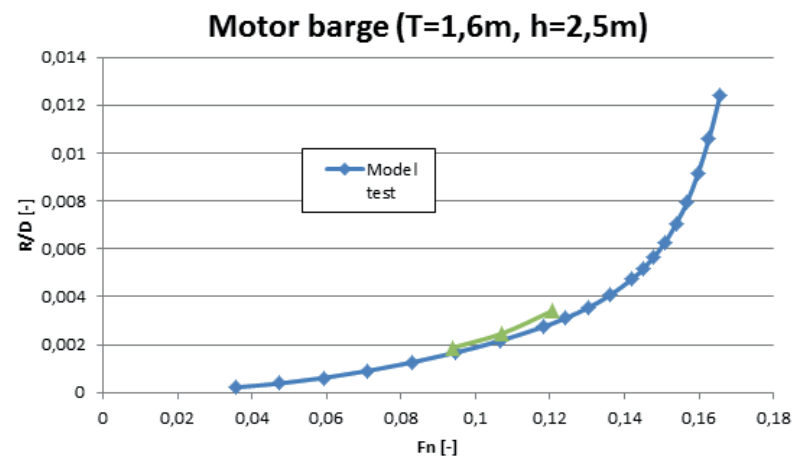

Fig. 1. R/D vs. Froude number. Results of model tests (scale 1:10) for Motor barge with a draught of $1.6 \mathrm{~m}$ and formula 1 [15]

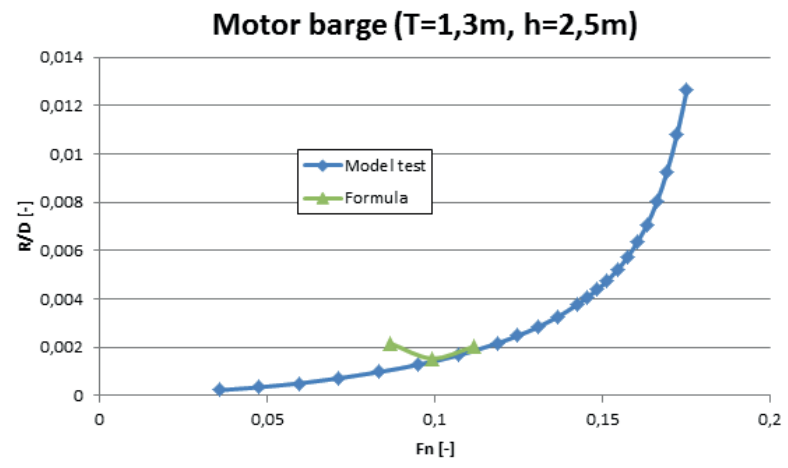

Fig. 2. R/D vs. Froude number. Results of model tests (scale 1:10) for Motor barge with a draught of $1.3 \mathrm{~m}$ and formula 1 [15] 


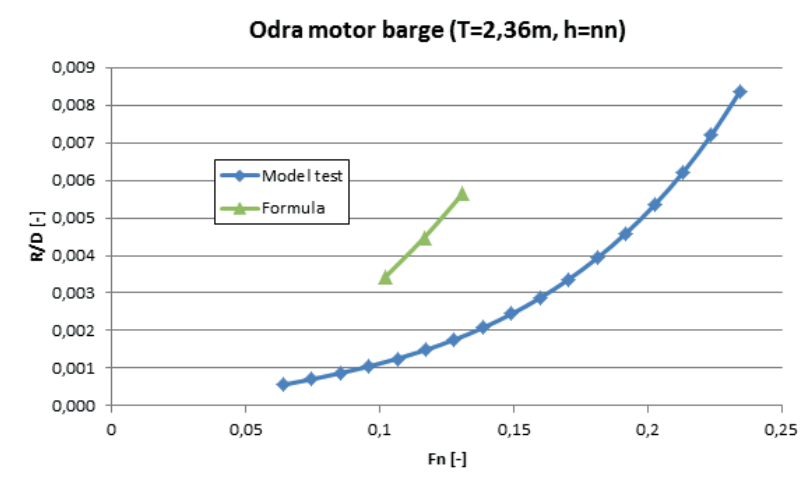

Fig. 3 R/D vs. Froude number. Results of model tests (scale 1:16) for Odra motor barge with a draught of $2.36 \mathrm{~m}$ and formula 1 [15]

The presented method gives a fairly good prediction of the resistance of a real object. Unfortunately, it cannot be directly applied in practice due to the very narrow range of Froude number (too narrow speed range).

Another method of calculation is presented in [8]. The analysis of the model tests was carried out for motor cargo vessels and pushed barge trains. To develop the formula, the regression analysis was used. The output was the equation:

$$
\frac{R_{T}}{D}=\left.\sum_{j=1}^{m} \sum_{i=0}^{8} a_{j i} \cdot X_{j}^{(i)}\right|_{F_{n=c o n s t}}
$$

where:

aji - regression equation coefficients,

$\mathrm{Xj}$ - independent variables $(\mathrm{Fn}, \mathrm{h} / \mathrm{T}, \ldots)$,

$\mathrm{i}$ - exponent.

For motor barges the following relation was obtained:

$$
\begin{gathered}
\frac{R_{T}}{D}=\left[-17766,7\left(F_{n}\right)^{3}+4,6 \cdot 10^{5}\left(F_{n}\right)^{4}-\right. \\
+3,5393 \cdot 10^{6}\left(F_{n}\right)^{5}+8,80911 \cdot 10^{6}\left(F_{n}\right)^{6}- \\
+7,24856 \cdot \log \left(\frac{h}{T}\right)-0,024287 \cdot\left(\frac{L}{B}\right)^{2} \\
\left.+0,9245 \cdot\left(\frac{B}{T}\right)\right] \cdot 10^{-3}
\end{gathered}
$$

For pushed barge trains the following relation was obtained:

$$
\begin{gathered}
\frac{R_{T}}{D}=\left[3972,46\left(F_{n}\right)^{2}-14,59 \cdot 10^{4}\left(F_{n}\right)^{3}+\right. \\
+2,186 \cdot 10^{6}\left(F_{n}\right)^{4}-1,3843 \cdot 10^{7}\left(F_{n}\right)^{5}+ \\
+3,11949 \cdot 10^{7}\left(F_{n}\right)^{6}-0,076 \cdot \log \left(\frac{h}{T}\right) \cdot\left(\frac{B}{T}\right) \\
+0,232478\left(\frac{L}{B}\right)+0,209749 \cdot\left(\frac{B}{T}\right)- \\
\left.+5,35506 \cdot C_{B}\right] \cdot 10^{-3}
\end{gathered}
$$

The results obtained using this method are compared with the results of the model tests in Figs. 4, 5 and 6.

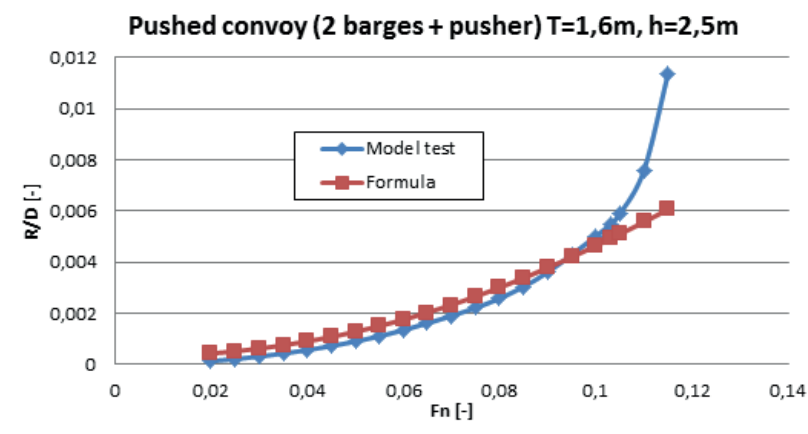

Fig. 4 R/D vs. Froude number. Results of model tests (scale 1:10) for pushed convoy with a draught of $1.6 \mathrm{~m}$ and formula 7 [15]

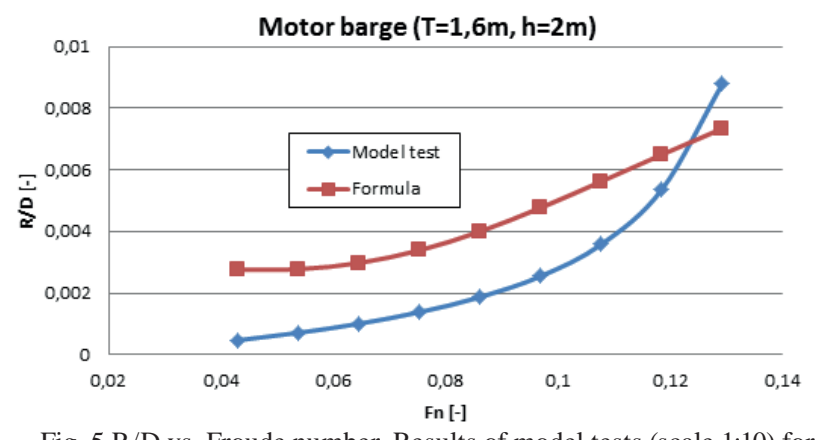

Fig. 5 R/D vs. Froude number. Results of model tests (scale 1:10) for motor barge with a draught of $1.6 \mathrm{~m}$ and formula 6 [15]

The scope of application of this method is not limited by its dependence on certain values of Froude number. However, discrepancies at high Froude numbers are relatively large, so it was reasonable to conduct further research for better methods to calculate the resistance of ships.

Estimation of resistance values of the pushed barge train is dependent on various geometrical and operational parameters, such as: speed and draught of the ship, depth and width of the waterway, length and width of the barge train, and other indirect parameters related to the barge train.

Good approximation of the barge train resistance is given by the Marchal's equation [9]:

$$
\begin{gathered}
\frac{R_{T}}{D}=\sum_{i=0}^{n_{1}} \sum_{j=0}^{n_{2}} \sum_{k=0}^{n_{3}} \sum_{l=0}^{n_{4}} \sum_{m=0}^{n_{5}} \sum_{n=0}^{n_{6}} \beta_{i j k l m n}\left(2 F_{r_{h}}\right)^{i}\left(10 F_{r h}\right)^{j} \\
\left(\frac{L}{\nabla^{\frac{1}{3}}} \cdot \frac{1}{10}\right)^{k}\left(\frac{1}{10} \frac{B}{h-T}\right)^{l}\left(5 \frac{B}{B_{c}}\right)^{m}\left(2 \frac{T}{h}\right)^{n}
\end{gathered}
$$

where: $\mathrm{Bc}$-width of the waterway.

In cases of motor cargo vessels, the accuracy of the estimated resistance values is not sufficient (Fig. 10). To obtain the equation defining the resistance of the motor cargo vessels, the regression analysis of the independent variable $\mathrm{R}$ was performed based on the experimental results. 


\section{Formula for motor cargo vessel resistance}

The experimental data was collected from the model tests [2], [3], [5] and [6], which included in total 194 measuring points, for different models of ships, their draughts and waterway depths.

\begin{tabular}{|l|c|c|c|c|c|c|c}
\hline \multirow{2}{*}{ Zmienna } & \multicolumn{6}{|c|}{ Korelacje (Arkusz5.sta) } \\
\cline { 2 - 8 } & V & T & h & I b & B & C & R \\
\hline V & 1,000000 & 0,2156339 & 0,346344 & 0,185124 & 0,132304 & 0,213997 & 0,761153 \\
\hline T & 0,215639 & 1,000000 & 0,233310 & 0,814209 & 0,694122 & 0,956800 & 0,373352 \\
\hline h & 0,346344 & 0,233310 & 1,000000 & 0,011545 & 0,089711 & 0,120880 & 0,063969 \\
\hline I-b & 0,185124 & 0,814209 & 0,011545 & 1,000000 & 0,930382 & 0,945291 & 0,382185 \\
\hline B & 0,132304 & 0,694122 & 0,089711 & 0,930382 & 1,000000 & 0,836225 & 0,352818 \\
\hline C & 0,213997 & 0,956800 & 0,120880 & 0,945291 & 0,836225 & 1,000000 & 0.396490 \\
\hline R & 0,761153 & 0,373352 & 0,063969 & 0,382185 & 0,352818 & 0,396490 & 1,000000 \\
\hline
\end{tabular}

Fig. 7 Correlation matrix for motor barges (changing signs for the program Statistica v $\left.=\mathrm{V}, \mathrm{l} \_\mathrm{B}=\mathrm{L}, \mathrm{C}=\nabla\right)$.

Figure 7 shows the correlation values for all 194 cases. The values marked red indicate high (significant) correlation between the variables. Some independent variables are strongly correlated, particularly variables $\mathrm{T}$ with $\mathrm{B}, \mathrm{L}, \mathrm{V}$ and $\mathrm{l}$ with $\mathrm{B}$ and $\mathrm{V}$.

\begin{tabular}{|c|c|c|c|c|c|c|c|}
\hline \multirow[b]{2}{*}{ Zmienna } & \multicolumn{7}{|c|}{$\begin{array}{l}\text { Korelacje (Arkusz5.sta) } \\
\text { Warunek uwzgledniania: Frice0,7 }\end{array}$} \\
\hline & v & $T$ & $\mathrm{~h}$ & Ib & B & C & $\mathbf{R}$ \\
\hline v & 1,000000 & 0,302498 & 0,446334 & 0,261224 & 0,215621 & 0,295950 & 0,832229 \\
\hline $\mathrm{T}$ & 0,302498 & 1,000000 & 0,160546 & 0,803692 & 0,678017 & 0,955484 & 0,538900 \\
\hline h & 0,446334 & 0.160546 & 1,000000 & $-0,075854$ & 0,007020 & 0,039631 & 0,222198 \\
\hline I b & 0.261224 & 0,803692 & $-0,075854$ & 1,000000 & 0,923863 & 0,941444 & 0,481405 \\
\hline$B$ & 0,215621 & 0,678017 & 0,007020 & 0,923863 & 1,000000 & 0,826375 & 0,445624 \\
\hline C & 0.295950 & 0,955484 & 0,039631 & 0,941444 & 0,826375 & 1,000000 & 0,536894 \\
\hline R & 0.832229 & 0,538900 & 0.222198 & 0.481405 & 0,445624 & 0.536894 & 1,000000 \\
\hline
\end{tabular}

Fig. 8 Correlation matrix for motor barges taking into account the condition of Frh $<0.7$ (changing signs for the program Statistica $\mathrm{v}=\mathrm{V}, \mathrm{l} \_\mathrm{B}=\mathrm{L}, \mathrm{C}=\nabla$ ).

Figure 8 shows the correlation for cases that satisfy the condition $\mathrm{F}_{\mathrm{rh}}<0.7$ (134 cases). Similarly, as shown in figure 7 , the values marked red show significant correlation between the variables. Strong correlation of variables can be observed, like for the data without considering the condition of $\mathrm{F}_{\mathrm{rh}}<0.7$. The level of correlation is slightly different.

Using the principal component analysis, new variables, uncorrelated with each other, were introduced. The independent variables used in the analysis were: $\nabla, \mathrm{h}, \mathrm{T}, \mathrm{B}, \mathrm{L}, \mathrm{V}$.

Due to the nonlinear nature of the phenomena it was decided to take advantage of adopting multiple regression of user as a function of the exponential function approximation.

$$
\operatorname{Reg}=\beta(z m 1)^{i}(\mathrm{zm} 2)^{j}(\mathrm{zm} 3)^{k}(\mathrm{zm} 4)^{m}(\mathrm{zm} 5)^{n}
$$

where $\beta$ - coefficient, $\mathrm{zm} 1, \ldots \mathrm{zm} 5$ are new independent variables in a dimensionless form, $\mathrm{i}, \mathrm{j}, \ldots \mathrm{n}$ - the sought values of the exponent. The Reg function itself is a dimensionless ratio of the resistance of movement of a motor cargo vessel and has the form:

$$
\operatorname{Reg}=\frac{R}{\nabla}
$$

The values of variables $\mathrm{zm} 1, \ldots \mathrm{zm} 5$ were determined using the relations shown in Table 1 .

Table 1. New dimensionless variables used in the multiple regression in Statistica v. 10

\begin{tabular}{|c|c|c|c|c|c|c|}
\hline \multirow[b]{2}{*}{ Zmienna } & \multicolumn{6}{|c|}{$\begin{array}{l}\text { Korelacje (Arkusz5.sta) } \\
\text { Warunek uwzgledniania: Frh<0.7 }\end{array}$} \\
\hline & Frh & Fnl & Bht & L.3V & Th & $\mathrm{Rd}$ \\
\hline Frh & 1,000000 & 0,341083 & 0,370922 & 0,244421 & 0,560740 & 0,461099 \\
\hline Fnl & 0,341083 & 1,000000 & $-0,462476$ & $-0,155302$ & $-0,487131$ & 0,894334 \\
\hline Bht & 0.370922 & $-0,462476$ & 1.000000 & 0,039156 & 0.886095 & $-0,168978$ \\
\hline L3V & 0.244421 & $-0,155302$ & 0,039156 & 1,000000 & 0,183553 & -0.117649 \\
\hline Th & 0,560740 & $-0,487131$ & 0,886095 & 0,183553 & 1,000000 & $=0,242817$ \\
\hline $\mathrm{Rd}$ & 0,461099 & 0,894334 & $-0,168978$ & $-0,117649$ & $-0,242817$ & 1,000000 \\
\hline
\end{tabular}

\begin{tabular}{|c|c|c|}
\hline $\begin{array}{c}\text { New } \\
\text { variable }\end{array}$ & Formula & $\begin{array}{c}\text { Name of } \\
\text { variable used in } \\
\text { Statistica }\end{array}$ \\
\hline $\mathrm{zm} 1$ & $\mathrm{zm} 1=\mathrm{V} / \sqrt{\mathrm{gL}}$ & $\mathrm{Fnl}$ \\
\hline $\mathrm{zm} 2$ & $\mathrm{zm} 2=\mathrm{V} / \sqrt{\mathrm{gh}}$ & Frh \\
\hline $\mathrm{zm} 3$ & $\mathrm{zm} 3=\mathrm{B} /((\mathrm{h}-\mathrm{T}))$ & $\mathrm{Bht}$ \\
\hline $\mathrm{zm} 4$ & $\mathrm{zm} 4=\mathrm{L} / \mathrm{W}$ & $\mathrm{L} 3 \mathrm{~V}$ \\
\hline $\mathrm{zm} 5$ & $\mathrm{zm} 5=\mathrm{T} / \mathrm{h}$ & $\mathrm{Th}$ \\
\hline
\end{tabular}

Fig. 9 Correlation matrix for motor barges taking into account the condition of Frh $<0.7$ for new dimensionless variables (Table 1).

The correlation values for the new variables are shown in Fig.9. They reveal high correlation between variables Th and Bht, but further regression analysis showed that both variables are important to achieve correct results. Other correlations are relatively low, therefore all variables were adopted for further analysis.

The multiple regression analysis was performed with Statistica v. 10 on the basis of the module - Nonlinear Estimation - User regression and least squares. The method of Levenberg-Marquardt estimation [13] was adopted, assuming five independent variables zm1, ... zm5 presented in Table 1.

Due to the rapid increase in resistance of a ship approaching a critical speed, the data was limited to satisfy the condition F_rh $<0.7$. After taking into account the above condition, the number of valid measurement points was reduced to 134 .

The formula used for multiple regression analysis was based on the equation proposed by Marchal (8) and the Howe formula [14]: 


$$
R_{T}=1,0684(3,2808 T)^{0,6+\frac{15,24}{B_{C^{-}-B}}}
$$$$
\cdot \exp \left(\frac{0,445}{h-T}\right) L^{0,38} B^{1,19} V^{2}
$$

The user regression equation is shown as the product of the above suggested independent variables raised to the power of $\mathrm{i}, \mathrm{j}, \mathrm{k}, \mathrm{m}, \mathrm{n}$, respectively:

$$
\frac{R_{T}}{\mathrm{D}}=\left(F_{n_{L}}\right)^{i}\left(F_{r_{h}}\right)^{j}\left(\frac{B}{(h-T)}\right)^{k}\left(\frac{L}{\sqrt[3]{\nabla}}\right)^{m}\left(\frac{T}{h}\right)^{n}
$$

where: $D=\nabla \cdot \rho \cdot g$. For fresh water it was assumed $\rho=1000$ $\mathrm{kg} / \mathrm{m} 3$.

As a result of the regression analysis, it was found that the parameters of Equation (12) are significant $(p=0)$, and the values are given in Table 2.

Table. 2. Result of regression analysis for motor cargo vessels.

\begin{tabular}{|c|c|c|c|c|}
\hline & \multicolumn{4}{l}{$\begin{array}{l}\text { Dependent variable: } \frac{\mathrm{R}_{\mathrm{t}}}{\mathrm{D}} \\
\text { Confidence level: } 0,95(\alpha=0,05) \\
\text { Prerequisite taken into account: Frh }<0,7\end{array}$} \\
\hline Parameter & Value & Standard Error & $\begin{array}{c}\text { Lower limit of the } \\
\text { confidence interval }\end{array}$ & $\begin{array}{c}\text { Upper limit of the } \\
\text { confidence interval }\end{array}$ \\
\hline$i$ & 0,578008062 & 0,208459773 & 0,166155355 & 0,989860769 \\
\hline$j$ & 1,94793065 & 0,180702724 & 1,59091738 & 2,30494393 \\
\hline$k$ & 0,571213435 & 0,037566282 & 0,49699396 & 0,64543291 \\
\hline$m$ & $-2,83294974$ & 0,175014574 & $-3,17872498$ & $-2,48717451$ \\
\hline$n$ & $-1,50131499$ & 0,0797317522 & $-1,65884053$ & $-1,34378945$ \\
\hline
\end{tabular}

The results obtained using the Marchal formula (8), the Howe formula (11), and the developed regression equation (12), were compared with the results of the model tests. The comparison is presented in Figs. 10,11 and 12 for motor cargo vessels: OBM, BM500 and DUISBURG, respectively.

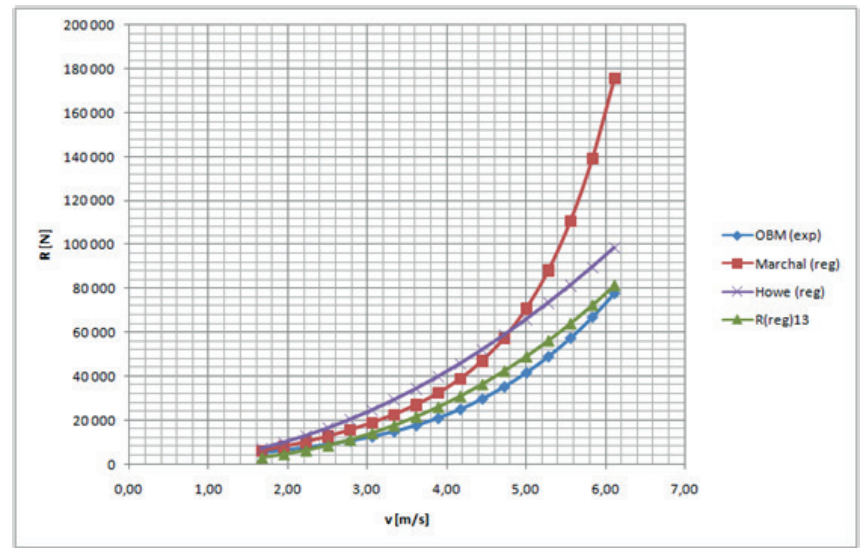

Figure 10. Estimations obtained using formulas proposed by Marchal and Howe, and the regression analysis (reg) equation (12) in relation to experimental studies (exp) for Odrzańska Barka Motorowa $\mathrm{B}=8,92 \mathrm{~m}$, $\mathrm{l}=67,83 \mathrm{~m}, \mathrm{~T}=1,6 \mathrm{~m}, \mathrm{~h}=16 \mathrm{~m}$. [15]

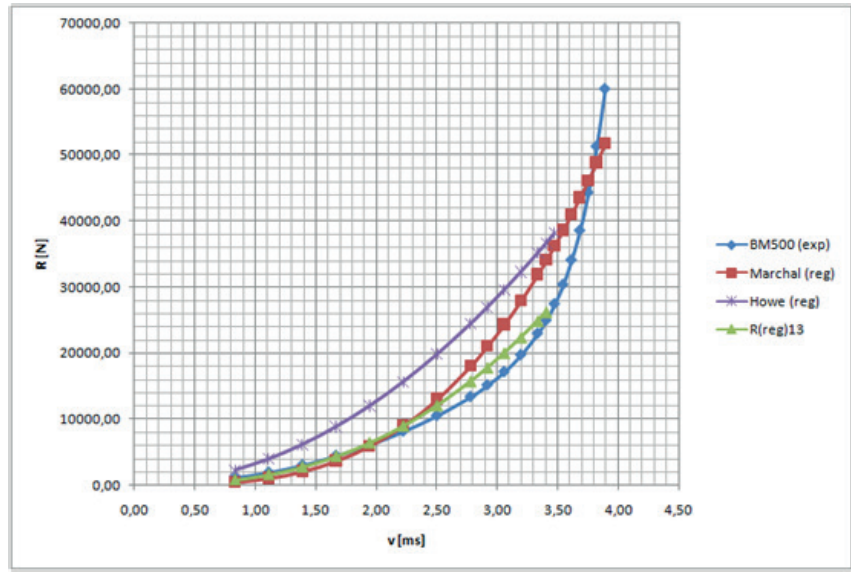

Figure 11. Estimations obtained using formulas proposed by Marchal and Howe, and the regression analysis (reg) equation (12) in relation to experimental studies (exp) for motor barge BM500: B=7,5 m, l=56,19 m, $\mathrm{T}=1,6 \mathrm{~m}, \mathrm{~h}=2,5 \mathrm{~m}$. [15]

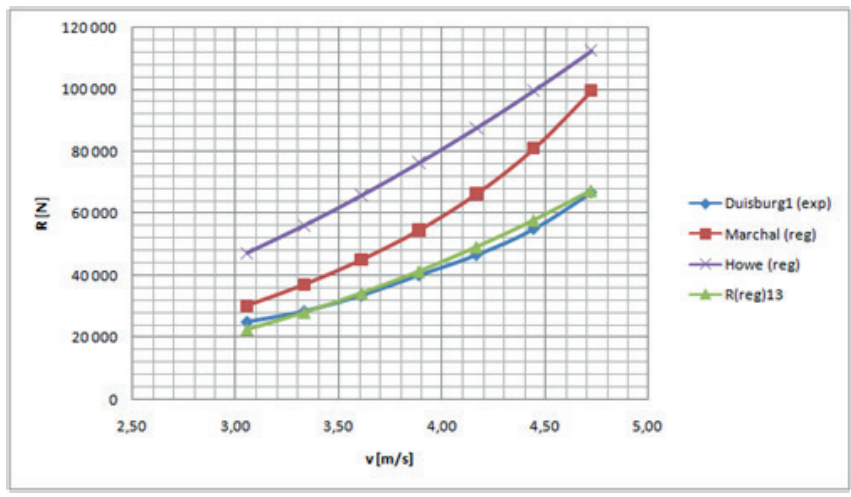

Figure 12. Estimations obtained using formulas proposed by Marchal and Howe, and the regression analysis (reg) equation (12) in relation to experimental studies (exp) for Duisburg1 (exp): $B=9,46$ m, L=85 m, T=2,5 $\mathrm{m}, \mathrm{h}=5 \mathrm{~m} .[15]$

\section{Conclusions}

The results shown in Figs. 10, 11 and 12 reveal that the Marchal method, that gives a good approximation for pushed barge trains, can be used for motor cargo vessels at small water depths, of an order of 2 to $2.5 \mathrm{~m}$. For larger depth, this method is insufficient. A model proposed by Howe (11) gives a fairly good approximation for water depth above 2 $\mathrm{m}$, while it is not sufficient for smaller depths.

The best approximation of the results of model tests for motor cargo vessels is provided by Equation (12). It should be emphasized that this equation enables to obtain results similar to those expected from experiments for motor cargo vessels of different shapes and in different navigation conditions. In addition, the calculation is not time consuming.

Figure 13 shows the observed values of $(\mathrm{R}(\mathrm{reg}))$ in relation to the expected values, for $F_{-}$rh $<0,7$.

The OX axis represents the values observed during the model tests, while the OY axis represents those obtained using different methods of calculation for the same parameters. 


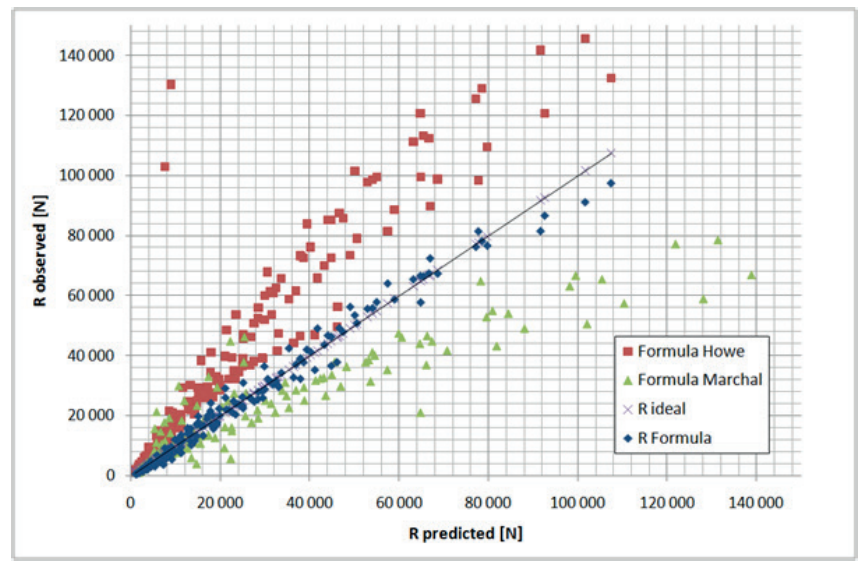

Fig.13 Distribution of observed versus predicted values for the regression equations of: Marchal, Howe and equation (12). [15]

Figure 13 illustrates that the resistance values predicted by the regression equation (12) for motor cargo vessels are close to the expected values for all cases Frh $<0.7$.

The above conclusion was used to estimate the fuel consumption during voyage on waterways with differential operating conditions. Based on the presented equations, a computer program has been written, and is still being developed with a future goal to make it available for on-board implementation.

\section{References}

1. Kulczyk J., Słomka A., Analiza regresyjna wyników badań modelowych statków śródlądowych, XIII Sesja Naukowa Okrętowców, Gdańsk 1988, str. 101-111

2. Systematische Modellversuche mit Schubleichterverbanden, Versuchsanstalt für Binnenschiffbau e.V. Duisburg. Bericht Nr. 778, Duisburg 1976

3. Schale E., Systematische Widerstands - und Propulsionsuntersuchungen an verschieden Schubboten Und Schubleichtern In Verband, sowie Gegenüberstellung des Schleppleistungsbedarfs fünfzehn unterschiedliches Schubformationen, Hanasa 99, Jahrgang 1962, nr 18.

4. Nawrocki S., Wyniki badań modelowych oporu zestawów pchanych, Politechnika Gdańska, Instytut Okrętowy, Gdańsk 1965

5. Modellversuchsergebnisse. Modell Nr. 683. MotorguterSchiff, Schiffbautechnische Versuchsanstalt In Wien, Wien 1958

6. Wyniki badań modelowych OBM /Model nr B430/ CTO. Ośrodek Hydromechaniki Okrętu, Gdańsk

7. Untersuchung der Nachstromverteilung an einem 2-Schrauben-Binnengutermotorschiff, Versuchsanstalt für Binnenschiffbau e.V. Duisburg. Bericht Nr. 788. Duisburg 1976

8. Kulczyk J., Prokopowicz J., Tabaczek T., Prognozowanie oporu statku śródlądowego w oparciu o wyniki badań modelowych, Politechnika Wrocławska, Raport serii: Sprawozdania nr 042/95, Wrocław 1995

9. Marchal J. L. J., Shen Y.-D., Kicheva D., An empirical formula to estimate the resistance of a convoy in a restricted waterway, Jurnal of ship research, vol. 40, No. 2, June 1996, pp. 107-111

10. Neter J., Kutner M.H., Nachtsheim C.J., Wasseman W., Applied linear statistical models, Fourth Edition, WBC MacGaw -Hill, Boston 1996

11. Stanisz A., Przystępny kurs statystyki z zastosowaniem STATISTICA PL na przykładach $\mathrm{z}$ medycyny. Tom 2 . Modele liniowe i nieliniowe, StatSoft Polska Sp. z o. o., Karków 2007

12. Stanisz A., Przystępny kurs statystyki z zastosowaniem STATISTICA PL na przykładach $z$ medycyny. Tom 3. Analizy wielowymiarowe, StatSoft Polska Sp. z o. o., Karków 2007

13. Brandt S., Analiza danych: metody statystyczne i obliczeniowe, PWN, Warszawa, 2002

14. Howe C. W., Mathematical model of barge tow performance, Jurnal of the waterway and harbors division, proceedings, American Society of Civil Engineers, 1976

15. Skupień E., Metoda doboru parametrów pracy układu napędowego statku śródlądowego przy zmiennej głębokości drogi wodnej, raport serii PRE nr 5/2014, Politechnika Wrocławska, Wrocław 2014

\section{CONTACT WITHE THE AUTOR}

\author{
Emilia Skupień \\ Jarosław Prokopowicz
}

Wrocław University of Technology

Faculty of Mechanical Engineering

5 Łukasiewicza St.

50-371 Wrocław

Poland 